\title{
The Variation Test And Extraction Equipment On Optimum Asphale Research By Using Gasoline Solvent
}

\author{
Fitridawati Soehardi \\ Universitas Lancang Kuning, Pekanbaru, 28265, Indonesia, \\ Tel/Fax: +62761 52324 \\ E-mail:fitridawati@unilak.ac.id
}

\begin{abstract}
Based on the Binamarga Specification 2010 at third revision, the extraction test should be carried out using the specimen from the loose asphalt mixture extracted from the back of the finisher bitumen machine. The purpose of this research is to find out the result of pretest and post test extraction asphalt content. The Extraction test using two equipment, they are Soklet and Centrifuge. The specimens used AMP, Asphalt Finisher and Core, which involved gasoline solvent. Based on the asphalt level extraction test results, the appropriate equipment was used centrifuge with the level accuracy as requirement of Binamarga Specification 2010 at third revision and the level of ease used as equipment in the field study. The asphalt content obtained for AMP 5,51\%, Asphalt Finisher5,46\% and Core 5.34\%. As for the socket asphalt content obtained is AMP 5.55\%, Asphalt Finisher 5.50\% and Core core 5. 41\%. The extract test value of asphalt content decreased, so it can be formulated KA JMF <KA AMP <KA Asphalt Finisher <KA Core. The value of Job mix used was 5.56\% with the tolerance given according to Binamarga Specification 2010 at third revision is $\pm 0.30 \%$. In accordance with the results obtained then the results of a centrifuge tool that matches and meets the requirements of time, accuracy of results and economic value.
\end{abstract}

Keywords: Extraction, centrifuge, socket, Asphalt Level, Gasoline

\section{Introduction}

Based on the 2010 Revised Specification of Binamarga 2010 , the extraction test be carried out using the specimen from the loose asphalt mixture extracted from the back of the finisher bitumen machine. Implementation of the field found asphalt content of extracted test results are not appropriate and reduced from the value of bitumen levels of Job Mix Formula.

Asphalt content is one of the most important parameters in the overall quality of concrete asphalt pavement in addition to its gradation and aggregate properties. If the bitumen content is less than required, there will be surface defect in the form of hole, release of grain while if the asphalt content is bigger than required, there will be crack in the form of crack shrink, curly, obesity, etc.

Gasoline is a mixture of various hydrocarbons obtained by distillation or refining of crude oil. The quality of gasoline is expressed by the octane number of 80 . The reason gasoline is used in this study that gasoline is easy found in the field as well as facilitates the extraction testing.

The purpose of this research is to find out the result of bitumen content in pre test and post test extraction. Extracting test using two tools that is Soklet and Centrifuge. This study uses the test specimens which taken from combination of asphalt production, gasoline was used during slap and compation field.

Several related researches, first Hadijah, conducted that extraction tests of appropriate bitumen content that used inthis research was using Centrifuge with gasoline solvent with the level of accuracy to meet the requirements and level of ease of tools to be brought to the field (project) and solvent easily obtained. the second researcher is Shamier who was conducting asphalt test using socklet to core drill result but asphalt content of average value of asphalt STA $1+175=6,020 \%$ and STA $3+875=6,015 \%$, but the result did not match with job specification. the third research is Anggraini who used Pertamax plus as solvent in extraction of content dissolves bitumen than gasoline solvent. Where the deviation is obtained in AMP $-0,03 \%$, from finisher $-0,01 \%$, and core $-0,02 \%$. The next researcher is Putri she conducted extracting test on mixed AC-WC Gradation Mixture. The Extracting test on mixed AC-WC Gradation mixture The extraction asphalt level for the mixture behind the asphalt finisher has a $-0.05 \%$ deviation to mixed asphalt content in AMP.

The asphalt content of the extraction from the core had a deviation of $-0.08 \%$ against the mixed asphalt level behind the asphalt finisher. Soehardi conducted extraction analysis of asphalt content of AC-WC gradation mixture with coarse gasoline. The value of pore content after extraction decreased from JMF pore value of AMP, finisher, and coredrill test object was $1.062 \%, 0.823 \%, 0.878 \%$, with the mean value of deviation of $0.273 \%$. With the average value of pore content for AMP, finisher, and coredrill test object is $0.673 \%, 0.667 \%, 0.602 \%$ with the average value of deviation of $0.273 \%$.

\section{Literature Review \\ 2.1 Asphalt}

Asphalt or bitumen is a material that is visco-elastic blackish brown color that will soften and melt when it gets warm up and vice versa. This viscoelastic property makes the asphalt able to envelop and hold the aggregate firmly in place during the production process and the service life. Generally, asphalt is produced from petroleum refining, so called as hard asphalt. The degree of control performed at the stage of the distillation process will produce asphalt with special properties suitable for specific applications. 
The asphalt content is the percentage of the asphalt weight to the mixture that ranges from 4.5 to 7.5 percent. Appropriate asphalt content should be determined on the basis of Marsall's way of testing to obtain a mixture that meets the requirements.

The main function of asphalt for pavement forming process is mixing process before it is spread out and after it is spread differently. In the process of pre asphalt mixed with aggregate would be wrapped or enveloped totally grains, fill the pores between the grains, and seep into the pores of each grain. In the post-asphalt process fill the pores of the total layer.

\subsection{Paving Alloy Extraction.}

Extraction according to RSNI M-05- (2004) is the process of separating the mixture of two or more ingredients by adding a solvent which can dissolve one of the ingredients provide in the mixture. The extraction of asphalt mixture is necessary to recover the material composition according to the plan in order to maintain the quality of the asphalt mixture. Tests of asphalt content in asphalt mixtures should be made by companies producing at least twice a day mixture of asphalt morning and day or any production of 200 tons of asphalt mixture. There are three methods of testing the asphalt content of solvent extraction (extraction with solvent), nuclear asphalt content gauge and ignition furnace.

This research used two extraction methods in determining the bitumen content in the mixture that is the method of extracting test with Centrifuge device according to SNI 03-6894-2002. and Method of extraction testing with Soklet tool in accordance with SNI 03-3640-1994.

The formula for determining the extraction bitumen content is as follows:

$$
H=(A-(E+D) / A \times 100 \%
$$

Information :

$$
\begin{aligned}
& \mathrm{H}=\text { bitumen content of sample }(\%) \\
& \mathrm{A}=\text { Weight Sample before extraction (gram) } \\
& \mathrm{D}=\text { The weight of the paper filter (gram) } \\
& \mathrm{E}=\text { Weight sample after extraction (gram). }
\end{aligned}
$$

\subsection{Gasoline.}

Gasoline is also called Petrol. Gasoline is a mixture of various hydrocarbons obtained by the distillation / refining process of crude oil. The quality of gasoline is expressed by the octane number. Premium is a clear yellowish color distillate oil. The yellow color is due to the presence of an additional dye.

The octane number is a number that indicates how much pressure cann be give before the gasoline burns spontaneously. The name octane comes from octane (C8), because of all the molecules of the gasoline compound, octane which has the best compression properties. Octana can be compressed to a small volume without spontaneous combustion, unlike the spontaneous combustion. The heptane function is as solvent in the extraction. By having a high octane the fuel will have a complete combustion.

\section{Methodology}

The study was conducted using laboratory testing. Te aim of this research is to determine the bitumen content using two methods that refer to extraction testing with Centrifuge tools using SNI 03-6894-2002 and extraction testing with Soklet tool using SNI 03-3640-1994. Extracting test of bitumen content using gasoline solvent. In each specimen of AMP, asphalt finisher, and core. Sampling on Marpoyan-Lipat Kain road segment. The results were compared opposite the parameters reviewed ie the method of testing and the retrieval of specimens.

\section{Results and Discussion}

\subsection{Asphalt Content Using Centrifuge Method.}

\begin{tabular}{|c|c|c|c|c|}
\hline \multirow{2}{*}{ No } & \multirow{2}{*}{ Sample } & \multicolumn{2}{|c|}{ Asphalt Level (\%) } & \multirow{2}{*}{$\begin{array}{l}\text { Specification } \\
\text { Tolerance }(\%)\end{array}$} \\
\hline & & $\begin{array}{c}\text { Extraction } \\
\text { Results } \\
(\%)^{*}\end{array}$ & $\mathrm{JMF}(\%)$ & \\
\hline 1 & $A M P$ & 5,51 & 5,56 & $\pm 0,3$ \\
\hline 2 & $\begin{array}{c}\text { Aspal } \\
\text { Finisher }\end{array}$ & 5,46 & 5,56 & $\pm 0,3$ \\
\hline 3 & Core & 5,34 & 5,56 & $\pm 0,3$ \\
\hline
\end{tabular}

The recapitulation of asphalt extraction test results can be seen in a follow.

Table 1. Asphalt Levels In Mix After Extraction Using Centrifuge Method.

* Fitri analysis results (2014)

From the table it can be seen that the bitumen content of extracted using centrifuge method with gasoline solvent on the three test specimens decreased at AMP $0.13 \%$ deviation. Finisher $0.1 \%$ deviation, and core deviation $0.11 \%$. Tests of asphalt content were carried out by using Gasoline solvent as much as \pm 7 liters with the weight of specimen for each sample was $\pm 1200 \mathrm{~kg}$.

\subsection{Asphalt Levels Using the Socket Method.}

The recapitulation of asphalt extraction test results which can be seen in Table 2 is the result of extraction test Using Soklet Method. 
Table 2. Asphalt Levels In Mix After Extraction Using Soklet Method

\begin{tabular}{|c|c|c|c|c|}
\hline \multirow{2}{*}{ No } & \multirow{2}{*}{ Sampel } & \multicolumn{2}{|c|}{ Asphalt Level (\%) } & Specification \\
\cline { 3 - 5 } & $\begin{array}{c}\text { Extraction } \\
\text { Results (\%) }\end{array}$ & $\begin{array}{c}\text { JMF } \\
(\%)\end{array}$ & \\
\hline 1 & AMP & 5,55 & 5,56 & $\pm 0,3$ \\
\hline 2 & $\begin{array}{c}\text { Aspal } \\
\text { Finisher }\end{array}$ & 5,50 & 5,56 & $\pm 0,3$ \\
\hline 3 & Core & 5,41 & 5,56 & $\pm 0,3$ \\
\hline
\end{tabular}

From Table 2 be analized that asphalt level after extraction with Soklet method with gasoline solvent at AMP deviation 0,01\%, In Asphalt Finisher 0,06\% deviation, at Core $0,15 \%$ deviation. Tests of bitumen content were conducted by using Gasol solvent as much as \pm 1 liter with the weight of specimen for each sample is $\pm 150 \mathrm{~kg}$.

\subsection{Asphalt Test Result Analysis Extraction results from AMP, asphalt finisher, and core.}

The recapitulation of asphalt extraction test results which can be seen in Table 3 is the result of extraction test Using Centrifuge Method.

Table 3. Asphalt Test Result Result Extraction from AMP, asphalt finisher, and core

\begin{tabular}{|c|c|c|c|c|}
\hline \multirow{2}{*}{ No } & \multirow{2}{*}{ Sample } & \multicolumn{2}{|c|}{ Asphalt Level (\%) } & \multirow{2}{*}{$\begin{array}{c}\text { Specification } \\
\text { Tolerance } \\
(\%)\end{array}$} \\
\cline { 3 - 4 } & $\begin{array}{c}\text { Centrifuge } \\
*\end{array}$ & Soklet & \\
\hline 1 & AMP & 0,05 & 0,01 & $\pm 0,3$ \\
\hline 2 & Finisher & 0,10 & 0,06 & $\pm 0,3$ \\
\hline 3 & Core & 0,22 & 0,15 & $\pm 0,3$ \\
\hline
\end{tabular}

From Table 3 it can be seen that the bitumen content of extracted by using two extraction methods has decreased from JMF value but still in tolerance of Binamarga
Specification 2010 revision 3. Deviation value of decrease of bitumen content Soklet Method for AMP is $0,04 \%$. The finisher is $0.4 \%$, and the core is $0.7 \%$ lower than using the centrifuge method.

Extraction testing method used Soklet tool with gasoline solvent which more precisely used in extraction testing, it can be seen from the test result has obtained asphalt level at AMP is 5,55\% close to asphalt level value at JMF. This proves that asphalt content is more extracted. However, this test can only be carried out in laboratories with a sample weight of $\pm 150 \mathrm{gr}$. So it is difficult to determine the aggregate filter analysis.

Extraction testing method using Centrifuge tool with gasoline solvent is more appropriate to be used in field extraction testing because it is practical in use, and the extract test data obtained is aggregate filter analysis and bitumen content on AMP is 5,51\% smaller than using soklet method. This test can be used in the field because of its practical use with a sample weight of \pm 1200 gr. So it can be easier in determining aggregate filter analysis.

\section{Conclusions.}

Extraction test results of asphalt content decreased, so it can be formulated KA JMF <KA AMP <KA Asphalt Finisher $<\mathrm{KA}$ Core. The value of Job mix used is $5.56 \%$ with the tolerance given by Bina marga Specification 2010 the third revision is $\pm 0.30 \%$, the AMP deviation value is $0.05 \%$. Asphalt Finisher is $0.10 \%$, and the core is $0.22 \%$. Extraction testing method using Centrifuge tools with solvents Gasoline is more appropriate to be used in extraction testing in the field because it is practical in the use meet the requirements of time, accuracy of results and economic value.

\section{References}

[1] Hadijah, Ida. 2011. “Evaluasi Variasi Bahan Pelarut Untuk Penentuan Kadar Aspal Optimum”, Jurnal Tapak, Vol 1 No.1.pp1-11.

[2] F.Soehardi, S.Wiyono, dan A.Wanim. 2014. "Kajian Perbandingan Kadar Aspal Hasil Ekstraksi Campuran AC-WC Gradasi Kasar Dengan Cairan Ekstraksi Menggunakan Bensin", Program Magister Teknik Sipil Universitas Islam Riau, Pekanbaru.

[3] Hadijah, Ida. 2011. “Evaluasi Variasi Bahan Pelarut Untuk Penentuan Kadar Aspal Optimum”, Jurnal Tapak, Vol 1 No.1.pp1-11.

[4] Shamier, Mochamad." Evaluasi Karakteristik Campuran Laston Asphalt Concrete Wearing Course", Tugas Akhir, Fakultas Teknik Sipil Universitas Kristen Maranatha.

[5] M.Anggraini, S.Wiyono, dan A.Wanim.2015.'Kajian Kadar Aspal Hasil Ekstraksi Penghamparan Campuran AC-WC Gradasi Kasar Dengan Job Mix Formula", Prosiding Seminar Teknik Sipil Annual Civil Engineering Seminar, ISBN 978-979-792-636-6, pp 96-103. 
[6] L.D.Putri, S.Wiyono, dan A.Puri.2015." Kajian Kadar Aspal Hasil Ekstraksi Penghamparan dan Mix Design Pada Campuran Asphalt Concrete Wearing Course (ACWC) Gradasi Halus", Prosiding Seminar Teknik Sipil Annual Civil Engineering Seminar, ISBN 978-979792-636-6, pp 117-123.

[7] F.Soehardi, S.Wiyono, dan A.Wanim. 2015. "Kajian Perbandingan Kadar Aspal Hasil Ekstraksi Campuran AC-WC Gradasi Kasar Dengan Cairan Ekstraksi Menggunakan Bensin", Prosiding Seminar Teknik Sipil Annual Civil Engineering Seminar, ISBN 978-979-792636-6, pp 137-144.

[8] Surat. 2015. "Perbandingan Metode Ektraksi Kadar Aspal Alat Centrifuge Extractor dengan Reflux", Jurnal INTEKNA, Tahun XIV No.1,PP 1-9.

[9] Badan Standardisasi Nasional (2004). Cara Uji Ektraksi kadar Aspal dari campuran beraspal menggunakan refluks Gelas. RSNI M-05-2004.

[10] Departemen Pekerjaan Umum (2002). Standar Nasional Indonesia Cara pengujian Kadar Aspla dari Campuran Beraspal Dengan Cara sentrifus. SNI 03-68942002.

[11] Departemen Pekerjaan Umum (1994). Standar Nasional Indonesia Metode Pengujian Kadar Beraspal Dengan Cara Ektraksi Menggunakan Alat Soklet. SNI 033640-1994.

[12] M.Anggraini, 2014, "Kajian Kadar Aspal Hasil Ekstraksi Penghamparan Campuran AC-WC Gradasi Kasar Dengan Job Mix Formula", Tesis, Program Magister Teknik Sipil Universitas Islam Riau, Pekanbaru. 